\title{
COMPOSIÇÃO DA REMUNERAÇÃO DE PROFESSORES DE REDES DE ENSINO ESTADUAIS*
}

\author{
COMPOSITION OF THE REMUNERATION OF TEACHERS OF STATE EDUCATION \\ NETWORKS
}

\begin{abstract}
Márcia Aparecida Jacomini Doutora em Educação pela Faculdade de Educação da Universidade de São Paulo (Feusp). Professora da Escola de Filosofia, Letras e Ciências Humanas da Universidade Federal de São Paulo (EFLCHUnifesp) Guarulhos, São Paulo, Brasil. jacominimarcia@gmail.com
\end{abstract}

Ana Paula Santiago do Nascimento Doutora em Educação pela Faculdade de Educação da Universidade de São Paulo (Feusp). Professora da Educação Básica, Técnico e Tecnológico na Universidade Federal de São Paulo (Unifesp) São Paulo, SP, Brasil. anpaula@usp.br

Kátia Aparecida dos Santos Imbó Doutoranda na Faculdade de Educação da Universidade Estadual de Campinas (Fecamp). Coordenadora Pedagógica da Rede Municipal de Ensino de São Paulo, São Paulo, SP, Brasil. katcabre@yahoo.com.br

Resumo: Neste artigo, a composição da remuneração docente é estudada com base nos planos de carreira. O objetivo é analisar a movimentação na carreira, com a respectiva diferenciação no vencimento-base, e as vantagens pecuniárias permanentes e transitórias que compõem a remuneração dos professores. Trata-se de estudo bibliográfico e documental, com investigação dos planos de carreira de redes de ensino de 12 estados brasileiros, em vigor no ano de 2014. Verificou-se que os planos de carreira preveem diferenças no vencimento-base de acordo com nível de formação, tempo de serviço, formação continuada e avaliação de desempenho, e que o conjunto de vantagens pecuniárias é bastante diversificado. A partir dos dados analisados, buscaram-se indicar aspectos que devem ser considerados na composição da remuneração para a valorização do professor, tendo em vista que o vencimento-base constitui o principal componente da remuneração.

Palavras-chave: Carreira docente. Remuneração de professores. Redes Estaduais de ensino. Valorização do professor.

Abstract: In this article the composition of the teaching remuneration is studied based on the career plans. The objective is to analyze the movement in the career and the respective differentiation in the basic salary and the permanent and transitory pecuniary advantages that compose the remuneration of teachers. It is a bibliographic and documentary study with investigation of the career plans of education network from 12 Brazilian states, in force in the year 2014. It was verified that the career plans foresee difference in the basic salary by level of formation, length of service, continuing education and performance evaluation and that the set of pecuniary advantages is quite diversified. From the analyzed data, it was intended to indicate aspects that must be considered in the composition of the remuneration, in view of the appreciation of the teacher, emphasizing the importance of basic salary as the main component of the remuneration.

Keywords: Teachers' remuneration. State education networks. Teacher appreciation. Teaching career.

Para citar - (ABNT NBR 6023:2018)

JACOMINI, Márcia Aparecida; NASCIMENTO, Ana Paula Santiago do; IMBÓ, Kátia Aparecida dos Santos. Composição da remuneração de professores de redes de ensino estaduais. Eccos - Revista Cientifica, São Paulo, n. 52, p. 1-25, e11159, jan./mar. 2020. Disponível em: https://doi.org/10.5585/eccos.n52.11159. 


\section{Introdução}

Os estudos sobre remuneração docente que comparam os salários de professores com os de outros profissionais com formação equivalente partem de dados informados pela Pesquisa Nacional por Amostra de Domicílios (Pnad) do Instituto Brasileiro de Geografia e Estatística (IBGE) ou de outras fontes que forneçam dados sobre salários de professores e não professores. Estudos como os de Alves e Pinto (2011), Barbosa (2011; 2014), Barbosa Filho e Pessôa (2011), Departamento Intersindical de Estatística e Estudos Socioeconômicos (2014), Instituto Nacional de Estudos e Pesquisas Educacionais Anísio Teixeira (2015), Liang (2003), Limarino (2005), Moriconi e Marconi (2008), entre outros, indicam a média remuneratória dos professores da educação básica e a comparação com a média salarial de outros profissionais com formação equivalente. Ao estabelecer comparação entre a remuneração média dos professores e a de outros profissionais, obtém-se informação importante para se pensar a valorização docente.

As análises empreendidas nesses estudos não contemplam informações sobre a composição da remuneração, ou seja, os elementos presentes nos planos de carreira e na política salarial do poder público que concorrem para compor a remuneração do professor. Assim, este estudo sobre a composição da remuneração, considerando os valores do vencimento-base - de acordo com a progressão na carreira por formação acadêmica, tempo de serviço, formação continuada e avaliação de desempenho - e as vantagens pecuniárias permanentes e transitórias conforme os planos de carreira, soma-se àqueles que têm investigado a remuneração docente com o objetivo de verificar a valorização desses profissionais, em termos salariais, em comparação com outros profissionais com formação equivalente.

Nesse sentido, o presente trabalho busca contribuir com informações para melhor compreensão da condição remuneratória dos professores no Brasil, a partir de estudo documental e bibliográfico (LAKATOS; MARCONI, 2001). Foram analisados os planos de carreira de 12 estados brasileiros (MG, MS, MT, PA, PB, PI, PR, RN, RR, RS, SC e SP) que estavam em vigor no ano de 2014, nos aspectos relacionados aos critérios de movimentação na carreira e à composição da remuneração, abrangendo, portanto, vantagens permanentes e temporárias que, somadas ao vencimento-base, compõem a remuneração do professor.

O objetivo do estudo é analisar a composição da remuneração e do vencimento a partir do que está previsto no plano de carreira dos professores, sem investigação dos respectivos valores. Entende-se que a movimentação na carreira, prevista nos planos, constitui um elemento de valorização da remuneração do professor, por meio da progressão do vencimento-base, 
considerando a qualificação acadêmica do docente, a formação continuada, o tempo de serviço e a avaliação de desempenho. Tendo em vista a importância de manter o professor na rede de ensino, é fundamental que a carreira seja atrativa, assim como a remuneração inicial, na medida em que, no decorrer da vida profissional, o professor terá os valores de seus vencimentos acrescidos.

Dessa forma, agregamos aos estudos sobre remuneração docente uma análise que não se atém aos valores dos salários, mas à forma como eles são compostos com base nos planos de carreira, de forma a apresentar ao leitor quais os critérios para o aumento do valor do vencimento-base durante a carreira profissional bem como as vantagens pecuniárias que compõem a remuneração do professor de educação básica.

\section{Vencimento-base e remuneração nos PCCR do professor da educação básica}

De acordo com os planos de cargo, carreira e remuneração (PCCR) analisados na pesquisa, a remuneração do professor é composta pelo vencimento-base e pelas vantagens pecuniárias permanentes e temporárias ${ }^{1}$, entendendo as primeiras como aquelas que o professor continuará recebendo após a aposentadoria.

Vencimento-base é a retribuição pecuniária pelo exercício do cargo público, cujos valores são acrescidos de acordo com a movimentação na carreira (vertical e horizontal). Nos planos estudados, a diferença no valor do vencimento ocorre com base na formação acadêmica, no tempo de serviço, na formação continuada e na avaliação de desempenho.

\subsection{Diferenciação no vencimento base por formação acadêmica}

Em todos os planos analisados está prevista diferenciação no vencimento-base por nível de formação. No entanto, há variações em relação aos percentuais e à forma como ela é especificada nas leis. Cabe esclarecer que, no Estado de Minas Gerais, com a implantação da Lei do Subsídio (MINAS GERAIS, 2010b), as progressões vertical e horizontal ficaram suspensas de 2010 a 2016. De acordo com a Lei de Diretrizes e Bases da Educação Nacional (LDB), Lei nº 9.394/1996, a formação dos docentes que atuam na educação básica deve ser em nível superior, em curso de licenciatura, admitida como formação mínima para trabalhar na educação infantil e séries iniciais do ensino fundamental aquela realizada em nível médio, modalidade Normal (BRASIL, 1996, art. 62).

Nos planos de carreira dos Estados do Pará e Roraima não está prevista formação em nível médio para ministrar aulas em qualquer etapa da educação básica. Nos demais estados há 
diferenciação entre o vencimento-base do professor com formação em nível médio e o com formação em nível superior. Ao observar a diferença entre um nível, faixa ou classe que representa a posição na tabela de vencimento, de acordo com a formação, percebe-se grande variação no vencimento-base inicial, que vai de $1,5 \%$ no Pará entre as classes até $130 \%$ no Mato Grosso e Rio Grande do Norte para professor com título de doutor.

Considerando o prescrito na LDB-1996 e o propósito de formar em nível superior a totalidade e em nível de pós-graduação 50\% dos professores da educação básica, de acordo com a Meta 16 do Plano Nacional de Educação (PNE) 2014-2024 (BRASIL, 2014), é salutar pensar que a diferença no vencimento por formação seja um incentivo para que o professor busque qualificar-se. Contudo, planos de carreira que propõem um vencimento final para professores com doutorado duas ou três vezes maior que o valor do vencimento inicial podem indicar uma falsa valorização do professor, uma vez que poucos ou nenhum professor da educação básica, dependendo da rede de ensino, atingem a formação em pós-graduação no nível de doutorado.

Nesse sentido, o mais interessante é incentivar a formação em nível superior e pósgraduação lato sensu em cursos vinculados à atuação profissional, que são mais próximos à realidade da maioria dos professores. Também é importante incentivar os professores que cursam mestrado e doutorado a permanecerem na educação básica, devido à qualificação desses profissionais.

A seguir, apresentam-se as diferenças percentuais no vencimento-base dos professores por nível de formação.

Na rede estadual do Paraná, o professor com formação em nível médio recebe $70 \%$ do vencimento inicial do docente com licenciatura plena. Para o professor com especialização, os valores são acrescidos de $25 \%$ em relação ao vencimento inicial do licenciado. Para o professor que participar do Programa de Desenvolvimento Educacional - que consiste em formação continuada promovida pelo governo do estado em nível de pós-graduação lato sensu -, está previsto percentual de $5 \%$ a mais em relação ao vencimento do professor com especialização. Esse percentual é calculado sobre o vencimento do professor com especialização na última referência possível.

No Rio Grande do Sul, entre os níveis I e IV, que compreendem os professores sem licenciatura plena, a diferença no vencimento inicial de um nível para outro é de $15 \%$; entre o professor com formação em nível médio, modalidade Normal, e o professor com licenciatura plena, é de $85 \%$; o vencimento dos professores com pós-graduação (especialização, mestrado e doutorado) corresponde ao dobro daqueles que têm somente nível médio. 
Chama a atenção, na rede estadual de Santa Catarina, o fato de o professor com licenciatura plena ganhar apenas $1 \%$ a mais que aqueles que têm somente magistério ou licenciatura curta. A diferença entre o professor com licenciatura plena e o pós-graduado (sem a especificação do tipo de curso) é de $23 \%$.

Em Minas Gerais, a diferenciação no vencimento entre o professor com formação em nível médio e licenciatura plena era de 17\% antes da Lei do Subsídio (MINAS GERAIS, 2010b).

Na rede estadual de São Paulo, o professor licenciado tem um acréscimo de 15,8\% no vencimento inicial em relação àquele com formação em nível médio. O professor de educação básica I com mestrado ou doutorado tem acréscimo de 21,6\% no vencimento inicial em relação ao graduado; no caso do professor de educação básica II, os percentuais para mestrado e doutorado em relação à graduação são, respectivamente, $15,8 \%$ e 21,6\%.

A diferenciação no vencimento-base inicial entre o professor com nível médio e o com nível superior é de $50 \%$ no Mato Grosso do Sul e no Mato Grosso. Entre os professores com formação em nível médio e em pós-graduação (doutorado, exceto no caso do Mato Grosso do Sul, cuja comparação é para o mestrado), a diferença fica acima de 50\%: Mato Grosso do Sul, $65 \%$, e Mato Grosso, $130 \%$.

A diferença no vencimento-base inicial do professor com formação em nível médio para aquele com nível superior é de $20 \%$ na Paraíba. Se o professor tiver especialização, são acrescidos mais 4,17\%; se mestrado, mais 4\%, e mais 3,86\% para o doutorado. Assim, a diferença entre o vencimento-base do professor com formação em nível médio e aquele com doutorado fica em torno de $35 \%$.

No Piauí, a diferença entre o professor com nível médio e aquele com licenciatura plena é de $22 \%$, a esse valor sendo acrescidos $15 \%$ se o professor tiver mestrado e $27 \%$ se também tiver doutorado.

No caso do Rio Grande do Norte, a diferença entre o professor formado em nível médio e o licenciado é de $40 \%$ no vencimento-base inicial; já um professor com doutorado recebe 130\% a mais em relação ao professor com formação em nível médio.

O Estado do Pará paga uma diferença fixa de 1,5\% entre os níveis por formação acadêmica, indiferentemente se é licenciado, especialista, mestre ou doutor.

Em Roraima, com exceção dos professores de educação indígena, é necessário ter licenciatura para lecionar na educação básica. Assim, entre o licenciado e o especialista tem-se uma diferença no vencimento-base inicial de $40 \%$ e, para os professores com mestrado e 
doutorado, ela chega a 30\%. Para o professor de educação indígena, a diferença entre formação em nível médio e licenciatura é de $40 \%$, e entre as demais, $30 \%$.

Observa-se que nem sempre há diferenciação no vencimento-base do professor com formação em ensino médio modalidade Normal e o professor com licenciatura que expresse valorização dessa formação, a exemplo de Santa Catarina. A valorização pela formação em nível de pós-graduação (especialmente mestrado e doutorado), considerando que são poucos os professores da educação básica que têm essa titulação, em alguns casos confere ao vencimentobase uma dispersão (diferença percentual entre o vencimento-base para formação em nível médio e o vencimento-base para formação em doutorado) muito alta, dando a impressão de uma carreira que incentiva a permanência dos professores na rede de ensino. Contudo, sendo reduzido o número de professores que acede ao topo da carreira no quesito formação acadêmica no nível de doutorado, na prática ela não constitui uma forma efetiva de valorizar o magistério público de educação básica.

Na Tabela 1, a seguir, são apresentados percentuais que diferenciam o vencimento-base do professor com formação em nível médio daquele com licenciatura, e do professor licenciado em relação àquele com pós-graduação, sem a especificação do nível em todos os casos (especialização, mestrado e doutorado).

Tabela 1 - Diferença percentual por nível de formação

\begin{tabular}{lll}
\hline Estado & $\begin{array}{l}\text { Diferença entre formação em nível } \\
\text { médio e em nível superior }(\%)\end{array}$ & $\begin{array}{l}\text { Diferença entre formação em nível superior e } \\
\text { pós-graduação }(\%)\end{array}$ \\
\hline MG & 17 & 0 \\
MS & 50 & 15 \\
MT & 50 & 1,5 \\
PA & 0 & \\
PB & 20 & 15 \\
PI & 22 & 15 (M) 27 (D) \\
PR & 30 & 25 \\
RN & 40 & 90 \\
RR & 0 & 40 (E) 30 (M/D) \\
RS & 85 & 25 \\
SC & 1 & 23 \\
SP & 15,8 & 21,6 (PEB I) 15 (M) 21,6 (D) (PEBII)
\end{tabular}

Fonte: A autora, com base em: MATO GROSSO (1998, 2004); MATO GROSSO DO SUL (2000, 2013); MINAS GERAIS (2004, 2005, 2008, 2010a, 2011); PARÁ (2010); PARAÍBA (2003); PARANÁ (2004, 2010); PIAUÍ (2006a); RIO GRANDE DO NORTE (2006); RIO GRANDE DO SUL (1974, 2011, 2014); RORAIMA (2013); SANTA CATARINA (1992, 2011a, 2013); SÃO PAULO (1997).

Legenda: E - especialização; M - mestrado; D - doutorado. 
A Resolução no 2/2009 da Câmara de Educação Básica do Conselho Nacional de Educação (CNE/CEB) traz orientação geral sobre valorização remuneratória por titulação, sem especificar percentuais para cada nível de formação (CONSELHO NACIONAL DE EDUCAÇÃO, 2009). Assim, cabe aos estados decidirem, com base nas realidades locais, os percentuais de valorização salarial de acordo com a titulação do professor.

No entanto, em sua proposta de projeto de lei sobre diretrizes nacionais para formulação dos planos de carreira, a Confederação Nacional dos Trabalhadores em Educação (CNTE) estabelece percentuais de acordo com a titulação:

IX - diferenciar os vencimentos ou salários iniciais da carreira dos profissionais da educação básica de que trata a presente Lei por titulação profissional, assegurando, no mínimo, diferença de 50\% (cinquenta por cento) entre os profissionais habilitados em nível médio profissional e em nível superior, $15 \%$ (quinze por cento), $25 \%$ (vinte e cinco por cento) e $35 \%$ (trinta e cinco por cento), respectivamente, entre os graduados em nível superior e os detentores de diplomas de especialização, mestrado e doutorado. (CONFEDERAÇÃO NACIONAL DOS TRABALHADORES EM EDUCAÇÃO, 2015, art. $4^{\circ}$ )

Nos estados em que há diferença entre a formação em nível médio e superior, ela varia de $1 \%$ a $85 \%$ nos Estados de Santa Catarina e Rio Grande do Sul, respectivamente. Na maioria dos estados, a diferença é inferior aos $50 \%$ propostos pela CNTE, indicando que a valorização remuneratória por formação em nível superior ainda é pequena na maioria dos planos analisados. Observa-se que, de acordo com a proposta da CNTE (2015), o maior percentual de diferenciação remuneratória deve ser entre o professor graduado e aquele formado em nível médio, indicando a importância dessa formação para atuar na educação básica e dialogando com a realidade do país, em que o número de professores pós-graduados na educação básica não chega a 50\%, considerando os níveis de especialização, mestrado e doutorado.

No que se refere à diferença por formação em nível de pós-graduação, observa-se diversidade de percentuais, sugerindo que ainda não há, entre os entes federados, muita clareza sobre a valorização remuneratória para esse nível de formação do professor da educação básica

\subsection{Diferenciação no vencimento-base por formação continuada, tempo de serviço e avaliação de desempenho}

Além da diferenciação no vencimento dos professores resultante da formação acadêmica, há diferenciação também por formação continuada, tempo de serviço e avaliação de desempenho.

Nos planos foram encontrados termos como promoção, progressão e evolução funcional, nem sempre com significados idênticos, mas todos indicando movimentação horizontal ou 
vertical na carreira. De acordo com os planos, também é bastante variado o percentual entre níveis, classes, referências, graus, entre outras denominações.

Em Minas Gerais, a movimentação na carreira por tempo de serviço, avaliação de desempenho e formação continuada é denominada progressão horizontal, com 15 graus (A-P), e o aumento no vencimento-base é de 3\% a cada mudança de letra. No Mato Grosso do Sul, essa movimentação é denominada promoção funcional (vertical), representada por oito classes (A-H), sendo que a diferença entre a classe A e a H é de 61\%. No Mato Grosso, essa progressão na carreira corresponde à movimentação vertical e é estipulada em níveis (1-12), sendo que a diferença entre o nível 1 e o 12 é de $59 \%$.

No Pará, trata-se da progressão horizontal, representada por 12 níveis (A-L), com diferença de $0,5 \%$ entre eles. Observa-se aqui uma movimentação na carreira que pouco modifica o vencimento-base do professor. Também no Rio Grande do Norte essa progressão se dá pela movimentação horizontal e é representada por dez classes (A- J), com diferença de 5\% entre as classes.

Em Roraima, a progressão horizontal envolve cinco padrões (I-V) em cada classe (as classes representam a movimentação pela via acadêmica), com diferença média de $5 \%$ entre um padrão e outro. Também chamada movimentação horizontal, em Santa Catarina a progressão na carreira por tempo de serviço, formação continuada e avaliação de desempenho corresponde a sete graus (A-G), com diferença de 3\% entre os graus. Para cada nível de formação há três referências, com diferença de $3 \%$ entre elas.

Em São Paulo, essa movimentação é denominada evolução funcional e é representada por oito níveis (I-VIII), com diferença de 5\% entre eles. Têm-se, ainda, oito faixas (1-8), que diferem de $10,5 \%$ entre uma e outra.

No Paraná são 11 classes (1-11), com diferença de 5\% entre elas. A movimentação horizontal no Piauí é representada por quatro níveis dentro de cada classe e apresenta diferença de $2 \%$ entre os níveis e de 3\% a 10\% entre as classes. No Rio Grande do Sul são seis classes (A-F), com diferença de $10 \%$ entre elas, perfazendo entre a primeira e a última um acréscimo de 50\%. Na Paraíba, trata-se de movimentação horizontal, com sete referências (I-VII) e diferença de $3 \%$ entre uma e outra.

$\mathrm{Na}$ Tabela 2, a seguir, apresenta-se a movimentação na carreira por tempo, formação continuada e avaliação de desempenho, com base na denominação, quantidade de steps e diferença percentual entre os steps ${ }^{2}$. 
Tabela 2 - Aspectos da movimentação por tempo de serviço, formação continuada e avaliação de desempenho

\begin{tabular}{llll} 
Estado & Denominação & Quantidade de steps & Diferença entre os steps (\%) \\
\hline \hline MG & Grau & $15(\mathrm{~A}-\mathrm{P})$ & 3 \\
MS & Classe & $8(\mathrm{~A}-\mathrm{H})$ & 61 (entre a classe A e a H) \\
MT & Nível & $12(1-12)$ & 59 (entre o nível 1 e o 12) \\
PA & Nível & $12(\mathrm{~A}-\mathrm{L})$ & 0,5 \\
PB & Referência & 7 (I-VII) & 3 \\
PI & Nível & $8(\mathrm{I}-\mathrm{VIII})$ & 5 \\
PR & Classe & $11(1-11)$ & 5 \\
RN & Classe & $10(\mathrm{~A}-\mathrm{J})$ & 5 \\
RR & Padrão & $5(\mathrm{I}-\mathrm{V})$ & 5 \\
RS & Classe & $6(\mathrm{~A}-\mathrm{F})$ & 10 \\
SC & Grau & $7(\mathrm{~A}-\mathrm{G})$ & 3 \\
SP & Faixa/nível & $8(1-8) / 8(\mathrm{I}-\mathrm{VIII})$ & $10,5 / 5$ \\
\hline
\end{tabular}

Fonte: A autora, com base em: MATO GROSSO (1998, 2004); MATO GROSSO DO SUL (2000, 2013); MINAS GERAIS (2004, 2005, 2008, 2010a, 2011); PARÁ (2010); PARAÍBA (2003); PARANÁ (2004, 2010); PIAUÍ (2006a); RIO GRANDE DO NORTE (2006); RIO GRANDE DO SUL (1974); RORAIMA (2013); SANTA CATARINA (1992, 2011a, 2013); SÃO PAULO (2005, 2009a, 2009b, 2011, 2013a).

A diferença percentual no vencimento-base entre os steps da carreira na movimentação por tempo de serviço, formação continuada e avaliação de desempenho varia de $0,5 \%$ a $10,5 \%$, sendo que para esta última movimentação há, no máximo, 15 degraus nos planos analisados. Observa-se diversidade no número de steps e no percentual.

Num exercício para definir uma progressão que valorize o vencimento-base do professor, podese considerar uma dispersão de, no mínimo, $100 \%^{3}$, isto é, no final da carreira o professor deve ter um vencimento-base cujo valor seja ao menos o dobro daquele do início de carreira. A partir desse parâmetro pode-se definir melhor o número de steps, o percentual entre eles e um interstício mínimo de progressão, de forma que o professor possa alcançar o topo da carreira antes da aposentadoria e que a movimentação na carreira seja um estímulo à permanência na docência.

\subsection{Vantagens pecuniárias que compõem a remuneração docente}

A remuneração do professor é composta pelo vencimento-base e as vantagens pecuniárias, que podem ser permanentes ou temporárias. Conhecer essa composição permite analisar se a política salarial do poder público está calcada na valorização do vencimento-base ou em vantagens pecuniárias que podem ser retiradas ou modificadas, especialmente as temporárias. 
Entre as vantagens pecuniárias permanentes, destaca-se a gratificação natalina ou $13^{\circ}$ salário, sendo de pagamento obrigatório garantido em lei. A gratificação natalina foi instituída pela Lei federal n 4.090, de 13 de julho de 1962 (BRASIL, 1962), no governo de João Goulart. A Constituição de 1988 considera como direito do trabalhador o "décimo terceiro salário com base na remuneração ou no valor da aposentadoria" (BRASIL, 1988, art. $7^{\circ}$, inciso VIII). Assim, todos os planos de carreira analisados contemplam o pagamento de $13^{\circ}$ salário ou gratificação natalina.

Dos 12 PCCR, cinco preveem o quinquênio a cada cinco anos de trabalho (PA, PB, PR, RN e SP) e um prevê o triênio, pago a cada três anos (RS). A sexta-parte, adicional pago quando o professor completa 20 anos de trabalho e que corresponde a um sexto do vencimento-base do professor, está presente somente no plano do Estado de São Paulo.

Ainda como vantagem permanente, o Estado do Pará paga adicional de titularidade e o de Santa Catarina, adicional de produtividade, de estímulo à regência de classe e por tempo de serviço. No Pará, o quinquênio representa $5 \%$ do vencimento do cargo e, ao completar 25 anos, o professor recebe o correspondente a 10\%. No Rio Grande do Norte o percentual também é 5\% do vencimento do cargo ou função e é pago até o limite de sete quinquênios. Em São Paulo ele é calculado na base de 5\% por quinquênio de serviço sobre o valor do vencimento ou salário do cargo ou função-atividade.

No Paraná, o quinquênio é calculado da seguinte forma: cinco anos - 5\%; dez anos $-10 \%$; 15 anos - 15\%; 20 anos - 20\%; 25 anos - 25\%; 31 anos - 30\%; 32 anos - 35\%; 33 anos - 40\%; 34 anos $-45 \%$; 35 anos $-50 \%$. Observa-se que, a partir do $31^{\circ}$ ano de serviço público, ele é pago anualmente até o $35^{\circ}$ ano, quando equivale a $50 \%$ do vencimento do cargo.

Na Paraíba são pagos sete quinquênios, com o seguinte percentual sobre o vencimento-base do cargo ou função: o primeiro, $5 \%$, o segundo, $7 \%$, o terceiro, $9 \%$, o quarto, $11 \%$, o quinto, $13 \%$, o sexto, $15 \%$ e o sétimo, $17 \%$.

No Rio Grande do Sul, o adicional por tempo de serviço é pago a cada três anos, num limite de 12, e corresponde a $5 \%$ do vencimento do cargo ou função. O adicional por tempo de serviço do Estado de Santa Catarina é concedido à base de $6 \%$ do vencimento, acrescido do adicional pela produtividade, da gratificação pelo estímulo à regência de classe e da gratificação de função, por triênio, até o máximo de 12 .

O quinquênio, o triênio e a sexta-parte são adicionais por tempo de serviço. Observa-se que, além da valorização do tempo de serviço na movimentação da carreira, alterando o vencimento-base, em metade dos planos analisados há adicional por tempo de serviço, cujo percentual sobre o vencimentobase compõe a remuneração. Tais vantagens premiam os professores ao valorizar seu tempo de trabalho dedicado ao ensino público, como se fosse um benefício futuro continuar na carreira docente.

Além das vantagens pecuniárias que o docente continuará recebendo após a aposentadoria, foram encontrados adicionais, gratificações, abonos e auxílios pagos por situações específicas e que não são incorporados à aposentadoria, aqui denominados vantagens pecuniárias temporárias. Os termos usados para se referir a essas vantagens pecuniárias não são iguais nos planos. Por exemplo: em alguns, a 
vantagem pecuniária pelo trabalho noturno é chamada de gratificação, em outros, de adicional. A despeito destas diferenças, o importante é verificar quais são as vantagens que compõem a remuneração dos docentes da educação básica, de acordo com os planos analisados.

Quadro 1 - Vantagens pecuniárias temporárias

\begin{tabular}{|c|c|}
\hline Vantagens temporárias & Estados \\
\hline $1 / 3$ de férias & $\begin{array}{l}\text { MG, MS, MT, PA, PI, PR, PR, RN, } \\
\text { RR, RS, SC, SP }\end{array}$ \\
\hline Adicional/gratificação de difícil acesso & MS, PI, RR, RS, SP \\
\hline Adicional/gratificação de insalubridade e periculosidade & PI, RN \\
\hline Adicional/gratificação por trabalho noturno & MS, PR, RN, RS, SP \\
\hline Auxílio alimentação & $\mathrm{SC}, \mathrm{SP}$ \\
\hline $\begin{array}{l}\text { Auxílio reclusão; auxílio para despesas quando transferido de } \\
\text { sede de trabalho }\end{array}$ & PB \\
\hline Auxílio transporte & MG, PI, PR, RN, SP \\
\hline Auxílio funeral & RR, SP \\
\hline $\begin{array}{l}\text { Gratificação de função de coordenação de área de } \\
\text { conhecimento; Gratificação de incentivo à docência; Auxílio } \\
\text { natalidade }\end{array}$ & $\mathrm{RR}$ \\
\hline Gratificação de função de coordenação pedagógica & PI, RR, SP \\
\hline Gratificação de função de vice-direção de escola & PI, RR, RS, SP \\
\hline $\begin{array}{l}\text { Gratificação de risco de vida e alta complexidade; Vantagem } \\
\text { pecuniária progressiva; Gratificação de escolaridade; } \\
\text { Gratificação de magistério }\end{array}$ & PA \\
\hline $\begin{array}{l}\text { Gratificação pela elaboração ou execução de trabalho técnico } \\
\text { ou científico; Gratificação pelo trabalho em regime de } 30 \text { ou } 40 \\
\text { horas semanais; Gratificação pela participação em órgão } \\
\text { colegiado; Gratificação por representação; Gratificação por } \\
\text { serviço extraordinário; Gratificação pela regência em classe } \\
\text { unidocência }\end{array}$ & $\mathrm{RS}$ \\
\hline $\begin{array}{l}\text { Gratificação pela ministração de aulas em cursos de } \\
\text { treinamento; Gratificação pela participação em banca } \\
\text { examinadora de concurso público; Gratificação por aulas } \\
\text { excedentes; Gratificação de incentivo à ministração de aula; } \\
\text { Gratificação de incentivo a regência de classe; Gratificação de } \\
\text { função especializada }\end{array}$ & $\mathrm{SC}$ \\
\hline $\begin{array}{l}\text { Gratificação pela participação em grupo de trabalho ou estudo, } \\
\text { nas comissões e em órgãos de deliberação coletiva }\end{array}$ & PI, SC \\
\hline
\end{tabular}




\begin{tabular}{|c|c|}
\hline Vantagens temporárias & Estados \\
\hline $\begin{array}{l}\text { Gratificação pela permanência no cargo após } 30 \text { anos de } \\
\text { magistério/ após adquirido direito à aposentadoria }\end{array}$ & PR, RS \\
\hline Gratificação pelo estímulo à regência de classe & $\mathrm{PA}, \mathrm{SC}$ \\
\hline Gratificação pelo exercício de função de confiança & PI, RS, SC \\
\hline Gratificação pelo exercício de função de direção & PB, PI, PR, RN, RR \\
\hline Gratificação pelo trabalho em educação especial & PI, PR, RR, RS \\
\hline $\begin{array}{l}\text { Gratificação por condição especial de trabalho; Abono de } \\
\text { permanência }\end{array}$ & PI \\
\hline Gratificação por dedicação exclusiva, diárias & $\mathrm{RN}$ \\
\hline 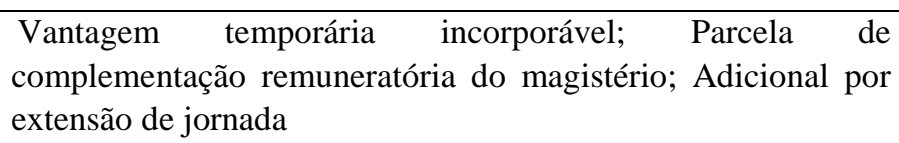 & MG \\
\hline
\end{tabular}

Fonte: A autora, com base em: MATO GROSSO (1998, 2013); MATO GROSSO DO SUL (2013); MINAS GERAIS (2005, 2007, 2008, 2010a, 2010b, 2011, 2012, 2013); PARÁ (2010); PARAÍBA (2003); PARANÁ (2004); PIAUÍ (1988, 1994, 2003, 2006a, 2006b, 2010a, 2010b, 2011, 2012, 2013); RIO GRANDE DO NORTE (2006); RIO GRANDE DO SUL (1974, 1981, 1985, 1988a, 1988b, 1989, 1992, 1994, 2003, 2012); RORAIMA (2001, 2013); SANTA CATARINA (1986, 1992, 2000, 2005, 2011a, 2011b, 2013); SÃO PAULO (1968, 1974, 1985, 1989a, 1989b, 1991, 1997, 2004, 2010, 2011, 2013b).

Em relação às vantagens pecuniárias temporárias, verifica-se grande diversidade (foram encontrados 41 tipos), embora algumas sejam comuns a vários estados.

Entre as vantagens temporárias com maior presença nos planos de carreira, encontram-se 1/3 de férias em todos ${ }^{4}$. A gratificação pelo exercício de função de direção é paga em seis estados (PB, PI, PR, RN, RR e RS ), o adicional ou gratificação de difícil acesso, em cinco (MS, PI, RR, RS e SP), assim como o adicional ou gratificação de trabalho noturno (MS, PR, RN, RS e SP ) e o auxílio transporte (MG, PI, PR, RN e SP). Nos planos de quatro estados há gratificação pelo trabalho em educação especial (PI, PR, RR, RS).

A forma como essas vantagens pecuniárias são pagas também tem variação entre os estados. No caso de Minas Gerais, elas foram incorporadas ao vencimento-base com a adoção da remuneração por subsídio. No Mato Grosso, que também adota remuneração por subsídio, a única vantagem pecuniária temporária é $1 / 3$ de férias, pago no mês de janeiro.

A gratificação de difícil acesso e por trabalho noturno (paga a partir das 18 horas) no Mato Grosso do Sul corresponde a 10\% do vencimento-base. Em Roraima, a gratificação pelo exercício em escola de difícil acesso incide sobre o vencimento inicial da classe da respectiva carreira, e não sobre o vencimento-base do professor, portanto, o valor é sempre o mesmo, independentemente da posição do professor na carreira. A gratificação de incentivo à docência representa um valor fixo, $\mathrm{R} \$ 732,00 \mathrm{em}$ valores de 2013, e é reajustada automaticamente com o mesmo índice aplicado ao reajuste dos 
vencimentos da carreira de magistério da educação básica e da carreira de magistério da educação indígena.

No Pará, a gratificação por dedicação exclusiva equivale a 30\% do vencimento-base e o adicional de insalubridade e periculosidade, a $20 \%$ do vencimento do cargo efetivo.

Em Santa Catarina, o professor que ministra aulas excedentes recebe 2,5\% por aula, calculado sobre o vencimento do cargo efetivo. As gratificações de incentivo à regência de classe, de incentivo à ministração de aulas e pelo exercício de função especializada de magistério correspondem ao percentual de 40\%, 20\% e 20\%, respectivamente, calculados sobre o valor do vencimento do cargo de provimento efetivo. A gratificação de incentivo à regência, paga aos ocupantes do cargo de professor que atuam na educação infantil, séries iniciais do ensino fundamental e educação especial, representa $40 \%$ do vencimento do cargo. O valor unitário do auxílio-alimentação em 2014 era $\mathrm{R}$ 12,00 por dia útil.

O pagamento de trabalho noturno no Estado de São Paulo compreende as aulas ministradas entre 19 e 23 horas e equivale a $10 \%$ do valor percebido por estas. A gratificação de função (funções de professor-coordenador e vice-diretor de escola) corresponde a $30 \%$ sobre o valor do vencimento relativo à Faixa 1, Nível I. O adicional de local de exercício é calculado mediante a aplicação de coeficientes sobre a Unidade Básica de Valor (UBV), de acordo com o local de trabalho. O auxílio-transporte na rede estadual paulista é calculado com base na diferença entre o valor estimado da despesa de condução do funcionário ou servidor e a parcela equivalente a 6\% de sua retribuição global mensal. O auxílioalimentação ocorre sob a forma de distribuição de documentos para aquisição de gêneros alimentícios. O valor do auxílio-funeral é igual a um mês de remuneração.

No Paraná, o adicional noturno corresponde a $25 \%$ do vencimento do nível e da classe em que o professor se encontra pelo trabalho realizado após as 18 horas. O auxílio transporte representa $24 \%$ do vencimento do professor, enquanto o abono permanência é pago da seguinte forma: 31 anos de trabalho - 30\% do vencimento do cargo, 32 anos - 35\%, 33 anos - 40\%, 34 anos - 45\%, 35 anos - 50\%.

O auxílio transporte no Piauí é relativo ao valor diário total de despesa com transporte coletivo municipal multiplicado por 22 dias úteis e descontados $6 \%$ sobre a retribuição mensal global do professor. Na Paraíba, a gratificação de estímulo à docência equivale a $40 \%$ do vencimento-base.

No Rio Grande do Sul, o pagamento da gratificação pelo exercício de direção é feito por meio da multiplicação do valor básico da gratificação por um índice de acordo com o padrão da unidade escolar e carga horária do profissional, podendo ir de 0,27 a 1,33; a gratificação de difícil acesso é calculada sobre o vencimento básico do quadro de carreira, conforme a classificação da escola de atuação, respectivamente, turno diurno e noturno; a gratificação pelo exercício em escola ou classe de alunos excepcionais representa $50 \%$ do vencimento-base; a gratificação pela regência em classe de unidocência equivale a 50\% do vencimento básico do quadro de carreira para o professor com regime de trabalho de 20 ou 30 horas semanais e $100 \%$ do vencimento básico do quadro de carreira para o professor com regime de trabalho de 40 horas semanais; a gratificação pelo exercício de função ocorre pela incorporação de parte ou do valor total da função gratificada ao servidor que, ao contar com 18 anos 
(sexo masculino) ou 15 anos (sexo feminino) de tempo de serviço computável à aposentadoria, houver exercido cargo em comissão; a gratificação de serviço extraordinário corresponde a 50\% em relação ao valor por hora normal de trabalho e acréscimo de $20 \%$ sobre o valor da hora de serviço extraordinário, se prestado em horário noturno; a gratificação de serviço noturno (entre 22 horas de um dia às 5 horas do dia seguinte) equivale a $20 \%$ do valor-hora; e a gratificação pela permanência no cargo depois de adquirido o direito à aposentadoria representa 50\% do vencimento-base do professor.

Sobre esse conjunto de vantagens pecuniárias temporárias, é importante destacar que, quando a vantagem corresponde a um percentual do vencimento-base do professor, ela é mais vantajosa ao profissional do que quando o percentual incide sobre o vencimento-base inicial da tabela de vencimentos. Nos planos de carreira analisados, encontram-se as duas situações, conforme descrito acima. Embora algumas vantagens pecuniárias temporárias sejam importantes porque representam garantia constitucional, como é o caso do $1 / 3$ de férias, ou uma especificidade a que apenas parte dos professores está sujeita, como o adicional/gratificação de trabalho noturno e de local de trabalho, o mais significativo na composição da remuneração é o professor ter um vencimento-base inicial compatível com as necessidades econômicas regionais (em razão do custo de vida) e a importância social da profissão, de forma que as vantagens temporárias não representem parte significativa da remuneração. Isto porque as vantagens podem deixar de existir ou a forma de pagamento pode ser modificada, ocasionando rebaixamento dos valores, entre outras adversidades que podem envolver esse tipo de vantagem pecuniária.

\section{Considerações finais}

Neste artigo, foram apresentadas e analisadas, com base nos planos de cargo, carreira e remuneração de 12 redes estaduais de ensino do país, a movimentação na carreira, a respectiva diferenciação no vencimento-base e a composição da remuneração que envolve o vencimento-base e as vantagens pecuniárias permanentes e transitórias.

De acordo com os dados analisados, verificou-se que na maioria dos planos há diferença no vencimento do professor com formação em nível médio e em nível superior, embora em algumas carreiras a formação em nível médio esteja em extinção. Dos 12 estados, apenas os PCCR de Mato Grosso e de Minas Gerais estabelecem como vencimento-base um subsídio fixo ao qual é vedado o acréscimo de gratificação, adicional, abono, prêmio, verba de representação ou qualquer outra espécie remuneratória.

Observou-se nos planos que o percentual de diferença no vencimento-base entre os níveis de formação é variado. Uma questão importante a se observar, em relação à diferença no vencimento-base pela formação acadêmica, é a grande valorização que alguns planos atribuem à formação em nível de mestrado e doutorado. Embora essa valorização seja importante, é necessário considerar que são poucos 
os professores da educação básica brasileira que cursam mestrado e doutorado. Também é importante considerar, do ponto de vista da carreira e da qualidade da educação, que a qualificação do professor em nível de pós-graduação seja vinculada ao trabalho que ele realiza em sala de aula, o que nem sempre acontece com o professor que faz a pós-graduação, especialmente nos cursos de mestrado e doutorado que têm como principal função formar o pesquisador e o professor universitário.

No que se refere à movimentação na carreira, que indica a passagem de um step a outro, encontrou-se grande diversidade na terminologia utilizada (grau, referência, classe, nível etc.); contudo, em todos os planos tratava-se de indicar a movimentação vertical e horizontal do professor na carreira por formação acadêmica, tempo de serviço, formação continuada, avaliação de desempenho. A diferença percentual entre os steps também é variável entre os planos de carreira, com percentual de 0,5\% a 10,5\%.

Em relação à amplitude da carreira, isto é, ao tempo necessário para se chegar ao topo, é importante considerar o tempo necessário à aposentadoria. Carreiras muito longas, com muitos steps, percentuais muitos baixos entre eles ou longos interstícios não contribuem para incentivar o professor a permanecer na rede de ensino, assim como carreiras muito curtas podem provocar uma espécie de acomodação, na medida em que, do ponto de vista remuneratório, o professor atinge o topo da carreira muito antes de concluir o tempo necessário à aposentadoria. Assim, para a valorização do vencimentobase, em termos de progressão na carreira, poder-se-ia pensar em interstícios de dois anos, com 12 steps e percentual de $8 \%$ entre eles. Isso significa que, para chegar ao topo da carreira, o professor trabalharia 24 anos e teria uma dispersão no vencimento em torno de $100 \%$.

Em relação às vantagens pecuniárias permanentes que compõem a remuneração docente encontram-se, além do $13^{\circ}$ salário, pago por todos os estados, adicionais por tempo de serviço na forma de triênio, quinquênio e sexta-parte. Na maioria dos planos, o percentual desses adicionais sobre o vencimento-base do professor é de 5\%, com exceção da sexta-parte, que corresponde a um sexto do vencimento-base do professor e que é paga somente no Estado de São Paulo. Essas vantagens são incorporadas à remuneração para efeito de aposentadoria, portanto, constituem parte importante da remuneração e representam valorização remuneratória pelo tempo de trabalho, incentivando a permanência nas redes públicas.

Há grande diversidade de vantagens pecuniárias transitórias nos planos de carreira, tendo sido encontrados 41 tipos. Elas compreendem desde 1/3 de férias, pago por todos os entes federados, até um conjunto de gratificações que é pago em apenas um estado. Sua incidência na forma de percentual sobre o vencimento ou de valor fixo também tem bastante variação, de acordo com os planos de carreira. Considerando que as vantagens pecuniárias temporárias referem-se a um acréscimo na remuneração do professor pela realização de trabalho em situação peculiar, pela realização de trabalho específico, por tempo determinado e por auxílios vinculados a direitos trabalhistas, é estranho encontrar gratificação por regência de classe ou algo similar, tendo em vista que ela constitui o trabalho para o qual o professor prestou concurso e ingressou na carreira do magistério. Isso pode ser compreendido no marco de uma política salarial que concede aumento na remuneração por meio de vantagens temporárias - ou 
"penduricalhos", como são denominados pelos professores - em detrimento do aumento no vencimentobase do professor, que é o valor com o qual ele se aposentará.

Nos planos de carreira analisados há três formas de pagamento das vantagens pecuniárias: percentual sobre o vencimento-base do professor, considerando a progressão na carreira, percentual sobre o vencimento-base inicial da carreira e valor fixo. A forma mais vantajosa é a aplicação de um percentual sobre o vencimento-base, posto que o percentual sobre o vencimento-base da carreira sempre será de menor valor do que aquele em que o percentual é aplicado ao vencimento de acordo com a posição do professor na carreira. O pagamento de um valor fixo, se por um lado tem maior impacto nas remunerações menores, por outro, pode ser desvalorizado quando da ausência de reajustes por longos períodos, a depender da política salarial do governo.

Ao considerar a composição da remuneração docente, é fundamental, do ponto de vista de sua valorização, que o vencimento-base - valor que não pode ser diminuído ou retirado e sobre o qual incidem as demais vantagens - seja a maior parte da remuneração. As vantagens pecuniárias que compõem a remuneração não se devem sobrepor ao vencimento-base, na medida em que são pagas de forma diferenciada e não atingem de forma igualitária todos os professores, com exceção do $13^{\circ}$ salário e do $1 / 3$ de férias. 
${ }^{*}$ Pesquisa financiada pela Capes - Edital Observatório da Educação de 2013.

${ }^{1}$ De acordo com o artigo 41 da Lei do Regime Jurídico Único, Lei federal no 8.112 (BRASIL, 1990), a remuneração é composta pelo vencimento do cargo efetivo acrescido das vantagens pecuniárias.

${ }^{2}$ Designamos por steps os graus, referências, classes ou faixas que compõem a carreira.

${ }^{3}$ Dutra Júnior e outros (2000) estabelecem como ideal uma dispersão na remuneração de aproximadamente $100 \%$.

${ }^{4} \mathrm{O}$ direito a $1 / 3$ de férias é constitucional (BRASIL, 1988 , art. $7^{\circ}$, inciso XVII).

\section{Referências}

ALVES, T.; PINTO, J. M. R. Características do trabalho docente no Brasil: um aporte. Cadernos de Pesquisa, São Paulo, v. 41, n. 143, p. 606-635, maio/ago. 2011.

BARBOSA, A. Salários docentes, financiamento e qualidade da educação no Brasil. Educação \& Realidade, Porto Alegre, v. 39, n. 2, p. 511-532, 2014.

BARBOSA, A. Os salários dos professores brasileiros: implicações para o trabalho docente. Brasília, DF: Liber Livro, 2011.

BARBOSA FILHO, F. H.; PESSÔA, S. A. A carreira de professor estadual no Brasil: os casos de São Paulo e Rio Grande do Sul. Revista de Administração Pública, Rio de Janeiro, v. 45, n. 4, p. 9651.001, jul./ago. 2011.

BRASIL. [Constituição (1988)]. Constituição da República Federativa do Brasil. Promulgada em 5 de outubro de 1988. Brasília, DF, 1988. Disponível em:

http://www.planalto.gov.br/ccivil 03/constituicao/constituicao.htm. Acesso em: 14 jan. 2017.

BRASIL. Emenda Constitucional no 41, de 19 de dezembro de 2003. Brasília, DF, 2003. Disponível em: http://www.planalto.gov.br/ccivil_03/constituicao/emendas/emc/emc41.htm. Acesso em: 23 jan. 2017.

BRASIL. Lei $n^{\circ}$ 4.090, de 13 de julho de 1962. Institui a Gratificação de Natal para os trabalhadores. Brasília, DF, 1962. Disponível em: http://www.planalto.gov.br/ccivil_03/leis/L4090.htm. Acesso em: 14 jan. 2017.

BRASIL. Lei $n^{\circ}$ 8.112, de 11 de dezembro de 1990. Dispõe sobre o regime jurídico dos servidores públicos civis da União, das autarquias e das fundações públicas federais. Brasília, DF, 1990. Disponível em: http://www.planalto.gov.br/ccivil 03/leis/18112cons.htm. Acesso em: 22 fev. 2020.

BRASIL. Lei $n^{\circ}$ 9.394, de 20 de dezembro de 1996. Estabelece as diretrizes e bases da educação nacional. Brasília, DF, 1996. Disponível em: http://www.planalto.gov.br/ccivil_03/leis/L9394.htm. Acesso em: 5 abr. 2016.

BRASIL. Lei $n^{o} 13.005$, de 25 de junho de 2014. Aprova o Plano Nacional de Educação - PNE e dá outras providências. Brasília, DF, 2014. Disponível em: http://www.planalto.gov.br/ccivil_03/_ato2011-2014/2014/lei/113005.htm. Acesso em: 29 mar. 2016.

CONFEDERAÇÃO NACIONAL DOS TRABALHADORES EM EDUCAÇÃO. Proposta de projeto de lei sobre diretrizes nacionais para os planos de carreira dos profissionais da educação escolar pública. Brasília, DF, 2015. Disponível em:

https://www.cnte.org.br/images/stories/2015/Minuta projeto diretrizes carreira VF.pdf. Acesso em: 23 dez. 2019. 
CONSELHO NACIONAL DE EDUCAÇÃO. Câmara de Educação Básica. Resolução $n^{\circ} 2$, de 28 de maio de 2009. Fixa as Diretrizes Nacionais para os Planos de Carreira e Remuneração dos Profissionais do Magistério da Educação Básica Pública, em conformidade com o artigo $6^{\circ}$ da Lei $n^{\circ}$ 11.738 , de 16 de julho de 2008, e com base nos artigos 206 e 211 da Constituição Federal, nos artigos $8^{\circ}$, § $1^{\circ}$, e 67 da Lei no 9.394, de 20 de dezembro de 1996, e no artigo 40 da Lei no 11.494 , de 20 de junho de 2007. Brasília, DF, 2009. Disponível em:

http://portal.mec.gov.br/dmdocuments/resolucao cne ceb002 2009.pdf. Acesso em: 5 abr. 2016.

DEPARTAMENTO INTERSINDICAL DE ESTATÍSTICA E ESTUDOS SOCIOECONÔMICOS. Nota técnica $n^{\circ} 141$. Transformações recentes no perfil do docente das escolas estaduais e municipais de educação básica. São Paulo: Dieese, 2014.

DUTRA JÚNIOR, A. F. et al. Plano de carreira e remuneração do magistério público: LDB, Fundef, diretrizes nacionais e nova concepção de carreira. Brasília, DF: MEC/Fundescola, 2000.

INSTITUTO NACIONAL DE ESTUDOS E PESQUISAS EDUCACIONAIS ANÍSIO TEIXEIRA. Plano Nacional de Educação - PNE - 2014-2024: linha de base. Brasília, DF, 2015. Disponível em: http://www.publicacoes.inep.gov.br/portal/download/1362. Acesso em: 14 jan. 2017.

LAKATOS, E. M.; MARCONI, A. Metodologia do trabalho científico: procedimentos básicos, pesquisa bibliográfica, projeto e relatório, publicações e trabalhos científicos. 6. ed. São Paulo: Atlas, 2001.

LIANG, X. Remuneración de los docentes en 12 países latinoamericanos: quiénes son los docentes, factores que determinan su remuneración y comparación con otras profesiones. Tradução M. B. Roldán. [s. 1.]: Preal, ago. 2003. Disponível em: https://www.yumpu.com/es/document/read/45214629/view-pdf-document-inter-american-dialogue. Acesso em: 23 fev. 2020.

LIMARINO, W. Are teachers well paid in LatinAmerica and Caribbean? Relative wages and structure of returns of teacher. In: VEGAS, E. (ed.). Incentives to improve teaching: lessons from Latin America. Washington, DC: World Bank, 2005. p. 63-102.

MATO GROSSO. Lei complementar $n^{\circ}$ 50, de $1^{o}$ de outubro de 1998. Dispõe sobre a Carreira dos Profissionais da Educação Básica de Mato Grosso. Cuiabá, 1998. Disponível em: http://app1.sefaz.mt.gov.br/Sistema/legislacao/LeiComplEstadual.nsf/9e97251be30935ed0325672700 3d2d92/178e4c93dbd56778042567c1006edf6b?OpenDocument. Acesso em: 6 jan. 2017. MATO GROSSO. Lei complementar $n^{\circ} 206$, de dezembro de 2004. Dispõe sobre alterações na Lei Complementar $\mathrm{n}^{\circ} 50$, de $1^{\circ}$ de outubro de 1998. Cuiabá, 2004. Disponível em: http://app1.sefaz.mt.gov.br/Sistema/legislacao/LeiComplEstadual.nsf/9733a1d3f5bb1ab38425671000 4d4754/8bd12dc7313c159b04256f850044d0db?OpenDocument. Acesso em: 16 jan. 2017.

MATO GROSSO. Lei complementar $n^{\circ}$ 510, de 11 de novembro de 2013. Dispõe sobre a Carreira dos Profissionais da Educação Básica de Mato Grosso. Cuiabá, 2013. Disponível em: www.al.mt.gov.br/storage/webdisco/leis/lei_5991.pdf. Acesso em: 6 jan. 2017.

MATO GROSSO DO SUL. Lei complementar $n^{\circ} 87$, de 31 de janeiro de 2000. Dispõe sobre o Estatuto dos Profissionais da Educação Básica do Estado de Mato Grosso do Sul e dá outras providências. Campo Grande, 2000. Disponível em: http://www.simtedpontapora.com.br/wpcontent/uploads/2010/08/Lei-Complementar-n\%C2\%BA-87 2000.pdf. Acesso em: 16 jan. 2017.

MATO GROSSO DO SUL. Lei complementar $n^{\circ} 174$, de 23 de maio de 2013. Altera a redação de dispositivos da Lei Complementar $n^{\circ} 87$, de 31 de janeiro de 2002, que dispõe sobre o Estatuto dos Profissionais da Educação Básica do Estado de Mato Grosso do Sul e dá outras providências. 
Campo Grande, 2013. Disponível em: http://www.jusbrasil.com.br/diarios/54780309/doems-24-052013-pg-1. Acesso em: 16 jan. 2017.

MINAS GERAIS. Decreto $n^{\circ} 46.125$, de 4 de janeiro de 2013. Regulamenta dispositivos da Lei $n^{\circ}$ 15.293, de 5 de agosto de 2004. Belo Horizonte, 2013. Disponível em:

http://www.almg.gov.br/consulte/legislacao/completa/completa.html?tipo=DEC\&num=46125\&ano=2 013. Acesso em: 15 jan. 2017.

MINAS GERAIS. Lei $n^{o} 15.293$, de 5 de agosto de 2004. Institui as carreiras dos profissionais de Educação Básica do Estado. Belo Horizonte, 2004. Disponível em: http://www.almg.gov.br/consulte/legislacao/completa/completa-novamin.html?tipo=Lei\&num=15293\&ano=2004. Acesso em: 16 jul. 2017.

MINAS GERAIS. Lei $n^{\circ}$ 15.787, de 27 de outubro de 2005. Institui a Vantagem Temporária Incorporável - VTI. Belo Horizonte, 2005. Disponível em:

http://ipsm.mg.gov.br/arquivos/legislacoes/legislacao/leis/lei_15787.pdf. Acesso em: 15 jan. 2017.

MINAS GERAIS. Lei 17.006, de 25 de setembro de 2007. Institui o piso remuneratório dos servidores do magistério público estadual. Belo Horizonte, 2007. Disponível em:

http://www.almg.gov.br/consulte/legislacao/completa/completa-novamin.html?tipo=Lei\&num=17006\&ano=2007. Acesso em: 15 jan. 2017.

MINAS GERAIS. Lei $n^{o} 17.600$, de $1^{\circ}$ de julho de 2008. Disciplina o Acordo de Resultados e o Prêmio por Produtividade no âmbito do Poder Executivo e dá outras providências. Belo Horizonte, 2008. Disponível em: http://www.ipsm.mg.gov.br/arquivos/legislacoes/legislacao/leis/lei_17600.pdf. Acesso em: 16 jan. 2017.

MINAS GERAIS. Lei 18.802, de 31 de março de 2010. Reajusta os valores das tabelas de vencimento básico das carreiras do Poder Executivo que menciona e dá outras providências Belo Horizonte, 2010a. Disponível em: http://ipsm.mg.gov.br/arquivos/legislacoes/legislacao/leis/lei_18802.pdf. Acesso em: 15 jan. 2017.

MINAS GERAIS. Lei $n^{\circ} 18.975$, de 29 de junho de 2010. Fixa o subsídio das carreiras do grupo de atividades de educação básica do poder executivo estadual e do pessoal civil da polícia militar do estado de Minas Gerais e dá outras providências. Belo Horizonte, 2010b. Disponível em: http://www.almg.gov.br/consulte/legislacao/completa/completa.html?tipo=Lei\&num=18975\&ano=20 10. Acesso em: 15 jan. 2017.

MINAS GERAIS. Lei $n^{\circ} 19.837$ de 2011. Promove alterações na política remuneratória das carreiras do Grupo de Atividades da Educação Básica e das carreiras do pessoal civil da Polícia Militar e dá outras providências. Belo Horizonte, 2011. Disponível em:

https://www.almg.gov.br/consulte/legislacao/completa/completa-novamin.html?tipo=LEI\&num=19837\&comp\&ano=2011\&texto=consolidado. Acesso em: 15 jan. 2017.

MINAS GERAIS. Lei $n^{\circ} 20.592$, de 28 de dezembro de 2012. Altera as Leis $\mathrm{n}^{\circ} \mathrm{s} 15.293$, de 5 de agosto de 2004, que institui as Carreiras dos Profissionais de Educação Básica do Estado, e 15.301, de 10 de agosto de 2004, que institui as Carreiras do Grupo de Atividades de Defesa Social do Poder Executivo, e dá outras providências. Belo Horizonte, 2012. Disponível em:

http://www.sindutemg.org.br/novosite/files/28-12-2012-lei-numero-20-592.pdf. Acesso em: 5 jan. 2017.

MORICONI, G. M.; MARCONI, N. Os salários dos professores públicos são atrativos no Brasil? Texto para discussão. São Paulo: Fundação Getúlio Vargas, 2008. Disponível em:

https://bibliotecadigital.fgv.br/dspace/bitstream/handle/10438/19487/CEPESP_Mariconi\%3b\%20Marc oni.pdf?sequence $=1 \&$ is Allowed=y. Acesso em: 26 fev. 20. 
PARÁ. Lei $n^{\circ}$ 7.442, de 2 de julho de 2010. Dispõe sobre o Plano de Cargos, Carreira e Remuneração dos Profissionais da Educação Básica da Rede Pública de Ensino do Estado do Pará e dá outras providências. Belém, 2010. Disponível em: http://www.consed.org.br/brasil-em-numeros/consedrhestudo-comparativo/plano-carreira/plano-de-carreira-pa.pdf. Acesso em: 16 jan. 2017.

PARAÍBA. Lei $n^{\circ} 7.419$, de 15 de outubro de 2003. Dispõe sobre o Plano de Cargos, Carreiras e Remuneração para o Grupo Ocupacional Magistério do Estado da Paraíba, e dá outras providências. João Pessoa, 2003. Disponível em:

http://201.65.213.154:8080/sapl/sapl_documentos/norma_juridica/7246_texto_integral. Acesso em: 16 jan. 2017.

PARANÁ. Lei complementar $n^{\circ} 103$, de 15 de março de 2004. Institui e dispõe sobre o Plano de Carreira do Professor da Rede Estadual de Educação Básica do Paraná e adota outras providências. Curitiba, 2004. Disponível em:

http://www.legislacao.pr.gov.br/legislacao/pesquisarAto.do?action=exibir\&codAto=7470\&indice $=1 \& t$ otalRegistros=1. Acesso em: 6 jul. 2016.

PARANÁ. Lei complementar $n^{\circ} 130$, de 14 de julho de 2010. Regulamenta o Programa de Desenvolvimento Educacional - PDE, instituído pela Lei Complementar $n^{\circ} 103 / 2004$, que tem como objetivo oferecer Formação Continuada para o Professor da Rede Pública de Ensino do Paraná, conforme especifica. Curitiba, 2010. Disponível em:

http://www.legislacao.pr.gov.br/legislacao/pesquisarAto.do?action=exibir\&codAto=56184\&indice $=1$ \&totalRegistros=2. Acesso em: 16 jan. 2017.

PIAUÍ. Decreto $n^{\circ} 15.011$, de 8 de dezembro de 2012. Altera o Decreto $\mathrm{n}^{\circ} 14.911$, de 3 de agosto de 2012, que dispõe sobre a concessão de auxílio-transporte a servidores públicos estaduais e a estagiários e determina o seu pagamento em pecúnia. Teresina, 2012. Disponível em: http://www.cge.pi.gov.br/legis/legislacao/decreto-estadual-15.011-2012-altera-decreto-14.911concessao-de-auxilio-transporte.pdf. Acesso em: 15 jan. 2017.

PIAUÍ. Decreto $n^{\circ} 15.476$, de 5 de dezembro de 2013. Altera o Decreto $\mathrm{n}^{\circ} 14.911$, de 3 de agosto de 2012, que dispõe sobre a concessão de auxílio-transporte a servidores públicos estaduais e a estagiários. Teresina, 2013. Disponível em:

http://legislacao.pi.gov.br/legislacao/default/atos/dec/2013. Acesso em: 15 jan. 2017.

PIAUÍ. Lei complementar $n^{\circ} 13$, de 3 de janeiro de 1994. Dispõe sobre o Estatuto dos Servidores Públicos Civis do Estado do Piauí, das autarquias e das Fundações públicas estaduais e dá outras providências. Piauí, 1994. Disponível em: http://legislacao.pi.gov.br/legislacao/default/ato/12457. Acesso em: 15 jan. 2017.

PIAUÍ. Lei complementar $n^{o} 28$, de 9 de junho de 2003. Dispõe sobre a Lei Orgânica da Administração Pública do Estado do Piauí e dá outras providências. Piauí, 2003. Disponível em: http://legislacao.pi.gov.br/legislacao/default/detalhe/12394. Acesso em: 15 jan. 2017.

PIAUÍ. Lei complementar $n^{o}$ 152, de 23 de março de 2010. Dispõe sobre o piso salarial profissional estadual para os profissionais do magistério público da educação básica, e dá outras providências. Teresina, 2010a. Disponível em: http://legislacao.pi.gov.br/legislacao/default/ato/14657. Acesso em: 15 jan. 2017.

PIAUÍ. Lei $n^{\circ} 71$, de julho de 2006. Dispõe sobre o Estatuto e o Plano de Cargos Carreira e Vencimento dos Trabalhadores em Educação Básica do Estado do Piauí e dá outras providências. Teresina, 2006a. Disponível em:

http://servleg.al.pi.gov.br:9080/ALEPI/sapl_documentos/norma_juridica/110_texto_integral. Acesso em: 5 jan. 2017. 
PIAUÍ. Lei $n^{\circ} 4.212$, de 5 de julho de 1988. Dispõe sobre o Estatuto do Magistério Público de $1^{\circ}$ e $2^{\circ}$ Graus do Estado do Piauí e dá outras providências. Teresina, 1988. Disponível em:

http://servleg.al.pi.gov.br:9080/ALEPI/sapl documentos/norma juridica/2435 texto integral. Acesso em: 25 jan. 2017.

PIAUÍ. Lei ordinária $n^{\circ}$ 5.589/2006. Fixa a remuneração dos Trabalhadores em Educação Básica do Estado do Piauí. Teresina, 2006b. Disponível em:

http://legislacao.pi.gov.br/legislacao/default/ato/12635. Acesso em: 15 jan. 2017.

PIAUÍ. Secretaria de Educação e Cultura. Portaria GSE/ADM no 0142, de 8 de abril de 2010. [Institui Condição Especial de Trabalho (CET) para o(s) cargo(s) e/ou funções de Diretor, Diretor Adjunto, Coordenador Pedagógico, Professor, Secretário, Secretário Adjunto, Auxiliar Administrativo, Vigia e Serviços Gerais]. Teresina, 2010b. Disponível em:

http://www.diariooficial.pi.gov.br/diario/201004/DIARIO13_64e8352286.pdf. Acesso em: 15 jan. 2017.

PIAUÍ. Resolução $n^{o} 1$, de 18 de março de 2011. Teresina, 2011. Disponível em: http://www.diariooficial.pi.gov.br/diario/201104/DIARIO04_9cc02f1054.pdf. Acesso em: 15 jan. 2017.

RIO GRANDE DO NORTE. Lei complementar $n^{o} 322$, de 11 de janeiro de 2006. Dispõe sobre o Estatuto e o Plano de Cargos, Carreira e Remuneração do Magistério Público Estadual, referente à Educação Básica e à Educação Profissional, e dá outras providências. Natal, 2006. Disponível em: http://www.consed.org.br/brasil-em-numeros/consedrh-estudo-comparativo/plano-carreira/plano-decarreira-rn.pdf. Acesso em: 16 jan. 2017.

RIO GRANDE DO SUL. Decreto $n^{o} 33.331$, de 25 de outubro de 1989.

Regulamenta a alínea "d" do item I do artigo 70 da Lei no 6.672, de 22 de abril de 1974. Porto Alegre, 1989. Disponível em:

http://www.al.rs.gov.br/legis/M010/M0100099.ASP?Hid Tipo=TEXTO\&Hid TodasNormas=18616 \&hTexto=\&Hid_IDNorma=18616. Acesso em: 28 fev. 2017.

RIO GRANDE DO SUL. Decreto $n^{\circ} 34.252$, de 1 de abril de 1992. Regulamenta a gratificação prevista no artigo 70, item I, letra "c", da Lei n" 6.672/74, alterado pelo artigo $1^{\circ}$, da Lei $n^{\circ}$ 8.646/88 e dá outras providências. Porto Alegre, 1992. Disponível em:

<http://www.al.rs.gov.br/legis/M010/M0100099.ASP?Hid_TodasNormas=16207\&hTexto=\&Hid_ID Norma $=16207>$. Acesso em: $28 \mathrm{fev} .2017$.

RIO GRANDE DO SUL. Decreto $n^{\circ} 48.743$, de 28 de dezembro de 2011. Regulamenta procedimentos para as Promoções dos Membros do Magistério Público Estadual, previstas na Lei no 6.672, de 22 de abril de 1974, e dá outras providências. Porto Alegre, 2011. Disponível em:

http://www.al.rs.gov.br/filerepository/repLegis/arquivos/DEC\%2048.743.pdf. Acesso em: 17 jan. $\underline{2017}$.

RIO GRANDE DO SUL. Decreto $n^{\circ} 52.085$, de 25 de novembro de 2014. Altera o Decreto $\mathrm{n}^{\circ}$ 48.743, de 28 de dezembro de 2011, que regulamenta procedimentos para as Promoções dos Membros do Magistério Público Estadual, previstas na Lei nº 6.672, de 22 de abril de 1974, e alterações, que instituiu o Estatuto e o Plano de Carreira do Magistério Público do Rio Grande do Sul. Porto Alegre, 2014. Disponível em:

http://www.al.rs.gov.br/legis/M010/M0100099.ASP?Hid_Tipo=TEXTO\&Hid_TodasNormas $=61638 \&$ hTexto $=\&$ Hid_IDNorma $=61638$. Acesso em: 16 jan. 2017.

RIO GRANDE DO SUL. Lei $n^{\circ}$ 6.672, de 22 de abril de 1974. Estatuto e Plano de Carreira do Magistério Público do Rio Grande do Sul. Porto Alegre, 1974. Disponível em: http://www.educacao.rs.gov.br/dados/lei_06672_20130311.pdf. Acesso em: 5 jan. 2017. 
RIO GRANDE DO SUL. Lei $n^{\circ} 7.597$, de 28 de dezembro de 1981. Dispõe sobre a gratificação de que trata o art. 70, item I, letra "a", da Lei n ${ }^{\circ} 6.672$, de 22 de abril de 1974. Porto Alegre, 1981. Disponível em: $\leq$ http://www.al.rs.gov.br/legis/M010/M0100099.ASP?Hid Tipo=TEXTO\&Hid TodasNormas=24 613\&hTexto=\&Hid_IDNorma=24613>. Acesso em: 28 fev. 2017.

RIO GRANDE DO SUL. Lei $n^{\circ} 8.112$, de 24 de dezembro de 1985. Dispõe sobre os regimes de trabalho dos funcionários públicos estaduais, estabelece limite de carga horária semanal para efeito de acumulação e dá outras providências. Porto Alegre, 1985. Disponível em:

〈http://www.al.rs.gov.br/legis/M010/M0100099.ASP?Hid_TodasNormas=21447\&hTexto=\&Hid_ID Norma $=21447>$. Acesso em: 28 fev. 2017.

RIO GRANDE DO SUL. Lei $n^{\circ}$ 8.646, de 7 de junho de 1988. Dispõe sobre o valor da gratificação prevista no artigo 70, item I, alínea c), da Lei no 6.672, de 22 de abril de 1974. Porto Alegre, 1988a. Disponível em:

<http://www.al.rs.gov.br/legis/M010/M0100099.ASP?Hid_Tipo=TEXTO\&Hid_TodasNormas=20100 \&hTexto=\&Hid_IDNorma=20100 $>$. Acesso em: 28 fev. 2017.

RIO GRANDE DO SUL. Lei $n^{\circ}$ 8.747, de 21 de novembro de 1988. Dispõe sobre o Quadro de Carreira, o Quadro em Extinção e as gratificações do Magistério Estadual, dando outras providências. Porto Alegre, 1988b. Disponível em: http://www.al.rs.gov.br/legis/M010/M0100099.ASP?Hid Tipo=TEXTO\&Hid TodasNormas=19388 \&hTexto=\&Hid_IDNorma=19388. Acesso em: 28 fev. 2017.

RIO GRANDE DO SUL. Lei $n^{\circ} 12.028$, de 18 de dezembro de 2003. Dispõe sobre a gratificação pelo exercício de direção de estabelecimento de ensino de que trata o artigo 96, parágrafo único, da Lei no 10.576, de 14 de novembro de 1995, incluído pela Lei n 11.695 , de 10 de dezembro de 2001. Porto Alegre, 2003. Disponível em: http://www.al.rs.gov.br/filerepository/repLegis/arquivos/12.028.pdf. Acesso em: 28 fev. 2017.

RIO GRANDE DO SUL. Lei $n^{\circ} 13.925$, de 17 de janeiro de 2012. Altera o art. 114 da Lei Complementar n..$^{\circ} 10.098$, de 3 de fevereiro de 1994, o art. 95 da Lei Complementar n. ${ }^{\circ} 13.452$, de 26 de abril de 2010, o art. 93 da Lei Complementar n. ${ }^{\circ} 13.453$, de 26 de abril de 2010, o art. 96 da Lei Complementar n. $^{\circ} 13.451$, de 26 de abril de 2010, dispõe sobre a gratificação de permanência em serviço para os membros do Magistério Público Estadual e para os servidores efetivos de que trata o art. $1^{\circ}$ da Lei n. ${ }^{\circ} 5.950$, de 31 de dezembro de 1969, e alterações, e dá outras providências. Porto Alegre, 2012. Disponível em:

http://files.comunidades.net/profemarli/LEI_13.925_GRATIFICACAO_DE_PERMANENCIA.pdf. Acesso em: 28 fev. 2017.

RIO GRANDE DO SUL. Lei complementar $n^{\circ} 10.098$, de 3 de fevereiro de 1994. (atualizada até a Lei Complementar n. ${ }^{\circ} 14.821$, de 30 de dezembro de 2015). Dispõe sobre o estatuto e regime jurídico único dos servidores públicos civis do Estado do Rio

Grande do Sul. Disponível em:

http://www.al.rs.gov.br/legiscomp/arquivo.asp?idNorma=527\&tipo=pdf. Acesso em: 28 fev. 2017.

RORAIMA. Lei complementar $n^{\circ} 53$, de 31 de dezembro de 2001. Dispõe sobre o Regime Jurídico dos Servidores Públicos Civis do Estado de Roraima e dá outras providências. Boa Vista, 2001. Disponível em:

http://www.tjrr.jus.br/legislacao/phocadownload/LeisComplementaresEstaduais/2001/lce\%20 n.\%20053\%20-\%20atualizada\%20-\%2001.pdf. Acesso em: 17 jan. 2017.

RORAIMA. Lei $n^{o}$ 892, de 25 de janeiro de 2013. Dispõe sobre a criação do Plano de Cargos, Carreiras e Remunerações dos Servidores da Educação Básica do Estado de Roraima (PCCREB), e dá 
outras providências. Boa Vista, 2013. Disponível em: http://www.imprensaoficial.rr.gov.br/diarios/doe-20130125.pdf. Acesso em: 5 jan. 2017.

SANTA CATARINA. Lei complementar $n^{\circ} 304$, de 4 de novembro de 2005. Incorpora o abono previsto na Lei ${ }^{\circ} 12.667$, de 2003, reajusta valores de gratificações previstas na Lei ${ }^{\circ}$ 1.139, de 1992, e estabelece outras providências. Florianópolis, 2005. Disponível em: http://leis.alesc.sc.gov.br/html/2005/304_2005_Lei_complementar.html. Acesso em: 23 fev. $\underline{2020 .}$.

SANTA CATARINA. Lei complementar $n^{\circ} 539$, de 18 de julho de 2011. Modifica o valor de vencimento, altera gratificações, absorve e extingue vantagens pecuniárias dos membros do Magistério Público Estadual, ativos e inativos, e estabelece outras providências. Florianópolis, 2011a. Disponível em: https://leisestaduais.com.br/sc/lei-complementar-n-539-2011-santa-catarina-modificao-valor-de-vencimento-altera-gratificacoes-absorve-e-extingue-vantagens-pecuniarias-dos-membrosdo-magisterio-publico-estadual-ativos-e-inativos-e-estabelece-outras-providencias. Acesso em: $23 \mathrm{fev}$. 2020 .

SANTA CATARINA. Lei complementar $n^{\circ}$ 592, de 20 de março de 2013. Modifica o valor de vencimento dos membros do Magistério Público Estadual, ativos e inativos, e estabelece outras providências. Florianópolis, 2013. Disponível em:

http://leis.alesc.sc.gov.br/oop/qfullhit.htw?CiWebHitsFile=\%2Falesc\%2Fdocs $\% 2 F 2013 \% 2 \mathrm{F5}$ 92_2013 lei_complementar\%2Edoc\&CiRestriction $=\% 28 \% 28 \% 40$ DocTitle $+592 \% 29+\mathrm{OR}+\%$ 28\%40DocKeywords $+592 \% 29 \% 29 \&$ CiBeginHilite $=\% 3$ Cstrong + class $\% 3$ DHit $\% 3 \mathrm{E} \& \mathrm{CiEndH}$ ilite $=\% 3 \mathrm{C} \% 2$ Fstrong $\% 3 \mathrm{E} \&$ CiUserParam $3=/$ PesquisaDocumentos. asp $\&$ CiHiliteType=Full. Acesso em: 17 jan. 2017.

SANTA CATARINA. Lei complementar promulgada $n^{\circ} 1.139$, de 28 de outubro de 1992. Dispõe sobre cargos e carreiras do Magistério Público Estadual, estabelece nova sistemática de vencimentos, institui gratificações e dá outras providências. Florianópolis, 1992. Disponível em:

https://leisestaduais.com.br/sc/lei-promulgada-n-1139-1992-santa-catarina-dispoe-sobre-cargos-ecarreiras-do-magisterio-publico-estadual-estabelecem-nova-sistematica-de-vencimentos-instituigratificacoes-e-da-outras-providencias-2015-12-28-versao-compilada. Acesso em: 23 fev. 2020.

SANTA CATARINA. Lei $n^{\circ}$ 6.844, de 29 de julho de 1986. Dispõe sobre o Estatuto do Magistério Público Estadual do Estado de Santa Catarina. Florianópolis, 1986. Disponível em: http://www.portaldoservidor.sc.gov.br/ckfinder/userfiles/arquivos/Legislacao\%20Correlata/Leis\%20O rdinarias/1986_-_LEI_ORDINARIA_N\%C2\%BA_6_844,_de_29_de_julho_de_1986.pdf. Acesso em: 23 fev. 2020.

SANTA CATARINA. Lei $n^{\circ} 11.647$, de 28 de dezembro de 2000. Autoriza o Poder Executivo a dispor sobre a concessão mensal de auxílio-alimentação por dia trabalhado aos servidores públicos civis e militares ativos da administração pública estadual direta, autárquica e fundacional, e adota outras providências. Florianópolis, 2000. Disponível em: http://leis.alesc.sc.gov.br/html/2000/11647_2000_Lei.html. Acesso em: 23 fev. 2020.

SANTA CATARINA. Lei $n^{\circ} 15.718$, de 23 de dezembro de 2011. Altera o $\S 6^{\circ}$ do art. $1^{\circ}$ da lei $\mathrm{n}^{\mathrm{o}} 11.647$, de 2000, que dispõe sobre a concessão mensal de auxílio-alimentação por dia trabalhado aos servidores públicos civis e militares ativos da administração pública estadual direta, autárquica e fundacional e adota outras providências. Florianópolis, 2011b. Disponível em: http://leisestaduais.com.br/sc/lei-ordinaria-n-15718-2011-santa-catarina-altera-o-6-do-art-1-da-lei-n11647-de-2000-que-dispoe-sobre-a-concessao-mensal-de-auxilio-alimentacao-por-dia-trabalhado-aosservidores-publicos-civis-e-militares-ativos-da-administracao-publica-estadual-direta-autarquica-efundacional-e-adota-outras-providencias. Acesso em: 23 jan. 2017. 
SÃO PAULO (Estado). [Constituição (1989)]. Constituição estadual, de 05 de outubro de 1989. São Paulo, 1989a. Disponível em:

http://www.al.sp.gov.br/repositorio/legislacao/constituicao/1989/constituicao-0-

05.10.1989.html. Acesso em: 26 jan. 2017.

SÃO PAULO (Estado). Decreto $n^{\circ} 30.595$, de 13 de outubro de 1989. Regulamenta a Lei n. ${ }^{\circ}$ 6.248, de 13 de dezembro de 1988, que institui o auxílio-transporte. São Paulo, 1989b.

Disponível em: http://www.al.sp.gov.br/repositorio/legislacao/decreto/1989/decreto-3059513.10.1989.html. Acesso em: 26 jan. 2017.

SÃO PAULO (Estado). Decreto $n^{\circ} 48.938$, de 13 de setembro de 2004. Dá nova redação a dispositivo do Decreto ${ }^{\circ}$ 34.064, de 28 de outubro de 1991, alterado pelo Decreto ${ }^{\circ} 39534$, de 17 de novembro de 1994, que trata de auxílio-alimentação. São Paulo, 2004. Disponível em: http://www.al.sp.gov.br/repositorio/legislacao/decreto/2004/decreto-4893813.09.2004.html. Acesso em: 26 jan. 2017.

SÃO PAULO (Estado). Decreto $n^{\circ}$ 49.394, de 22 de fevereiro de 2005. Regulamenta a Evolução Funcional, pela via não acadêmica, dos integrantes do Quadro do Magistério, prevista nos artigos 21, 22, 23 e 24 da Lei Complementar nº 836, de 30 de dezembro de 1997, alterada pela Lei Complementar no 958, de 13 de setembro de 2004. São Paulo, 2005. Disponível em: http://www.al.sp.gov.br/repositorio/legislacao/decreto/2005/decreto-4939422.02.2005.html. Acesso em: 17 jan. 2017.

SÃO PAULO (Estado). Decreto $n^{\circ} 55.078$, de 25 de novembro de 2009. Dispõe sobre as jornadas de trabalho do pessoal docente do Quadro do Magistério e dá providências correlatas. São Paulo, 2009a. Disponível em: http://www.al.sp.gov.br/repositorio/legislacao/decreto/2009/decreto-5507825.11.2009.html. Acesso em: 5 jan. 2017.

SÃO PAULO (Estado). Decreto $n^{\circ} 59.448$, de 19 de agosto de 2013. Altera e acrescenta dispositivos ao Decreto $\mathrm{n}^{\circ} 55.078$, de 25 de novembro de 2009, que dispõe sobre as jornadas de trabalho do pessoal docente do Quadro do Magistério e dá providências correlatas. São Paulo, 2013a. Disponível em: http://www.al.sp.gov.br/repositorio/legislacao/decreto/2013/decreto-59448-19.08.2013.html. Acesso em: 5 jan. 2017.

SÃO PAULO (Estado). Lei complementar $n^{\circ} 444$, de 27 de dezembro de 1985. Dispõe sobre o Estatuto do Magistério Paulista e dá providências correlatas. São Paulo, 1985. Disponível em: http://www.al.sp.gov.br/repositorio/legislacao/lei.complementar/1985/lei.complementar-44427.12.1985.html. Acesso em: 26 jan. 2017.

SÃO PAULO (Estado). Lei complementar $n^{\circ}$ 836, de 30 de dezembro de 1997. Institui Plano de Carreira, Vencimentos e Salários para os integrantes do Quadro do Magistério da Secretaria da Educação e dá outras providências correlatas. São Paulo, 1997. Disponível em:

http://www.al.sp.gov.br/repositorio/legislacao/lei.complementar/1997/lei.complementar-83630.12.1997.html. Acesso em: 5 jan. 2017.

SÃO PAULO (Estado). Lei complementar $n^{\circ} 1.094$, de 16 de julho de 2009. Institui a Jornada Integral de Trabalho Docente e a Jornada Reduzida de Trabalho Docente para os integrantes do Quadro do Magistério da Secretaria da Educação, cria cargos de docente que especifica. São Paulo, 2009b. Disponível em: http://www.al.sp.gov.br/repositorio/legislacao/lei.complementar/2009/lei.complementar1094-16.07.2009.html. Acesso em: 5 jan. 2017. 
SÃO PAULO (Estado). Lei complementar $n^{\circ} 1.123$, de 1 de julho de 2010. Altera as leis que especifica, e dá providências correlatas. São Paulo, 2010. Disponível em:

http://www.al.sp.gov.br/repositorio/legislacao/lei.complementar/2010/lei.complementar1123-01.07.2010.html. Acesso em: 26 jan. 2017.

SÃO PAULO (Estado). Lei complementar $n^{\circ} 1.143$, de 11 de julho de 2011. Dispõe sobre a reclassificação de vencimentos e salários dos integrantes do Quadro do Magistério da Secretaria da Educação, e dá providências correlatas. São Paulo, 2011. Disponível em: http://www.al.sp.gov.br/repositorio/legislacao/lei.complementar/2011/lei.complementar1143-11.07.2011.html. Acesso em: 17 jan. 2017.

SÃO PAULO (Estado). Lei complementar n $n^{\circ} 1.207$, de 5 de julho de 2013. Dispõe sobre os concursos públicos regionalizados para os integrantes do Quadro do Magistério da Secretaria da Educação, e dá providências correlatas. São Paulo, 2013b. Disponível em:

http://www.al.sp.gov.br/repositorio/legislacao/lei.complementar/2013/lei.complementar1207-05.07.2013.html. Acesso em: 5 jan. 2017.

SÃO PAULO (Estado). Lei no 500, de 13 de novembro de 1974. Institui o regime jurídico dos servidores admitidos em caráter temporário e dá providências correlatas. São Paulo, 1974.

Disponível em: http://www.al.sp.gov.br/StaticFile/documentacao/lei_500.htm. Acesso em: 26 jan. 2017.

SÃO PAULO (Estado). Lei $n^{\circ} 7.524$, de 28 de outubro de 1991. Institui Auxílio-Alimentação para funcionários e servidores da Administração Centralizada e dá providências correlatas.

São Paulo, 1991. Disponível em: http://www.al.sp.gov.br/repositorio/legislacao/lei/1991/lei7524-28.10.1991.html. Acesso em: 26 jan. 2017.

SÃO PAULO (Estado). Lei $n^{\circ} 10.261$, de 28 de outubro de 1968. Dispõe sobre o Estatuto dos Funcionários Públicos Civis do Estado. São Paulo, 1968. Disponível em: http://www.al.sp.gov.br/repositorio/legislacao/lei/1968/lei-10261-28.10.1968.html. Acesso em: 26 jan. 2017. 